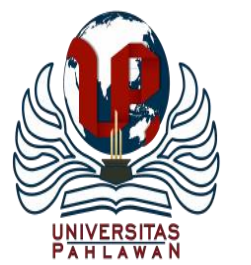

Edukatif : Jurnal Ilmu Pendidikan Volume 3 Nomor 6 Tahun 2021 Halm 3538 - 3543

EDUKATIF: JURNAL ILMU PENDIDIKAN

Research \& Learning in Education

https:/ledukatif.org/index.php/edukatif/index

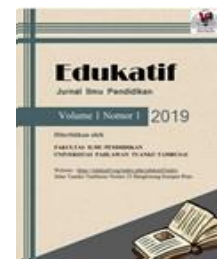

\title{
Pengaruh Media Pembelajaran Power Point Interaktif terhadap Hasil Belajar IPS Siswa Sekolah Dasar
}

\author{
Hanny Pramitha Putri ${ }^{1 凶}$, Nurafni ${ }^{2}$ \\ Universitas Muhammadiyah Prof. DR. Hamka, Indonesia ${ }^{1,2}$ \\ E-mail : pramithahanny@gmail.com ${ }^{1}$,nurafni@uhamka.ac.id²
}

\begin{abstract}
Abstrak
Selama pandemi Covid-19, diberlakukannya pembelajaran jarak jauh, maka perlunya memperhatikan proses pembelajaran. Observasi yang dilakukan peneliti menemukan masalah pada proses pembelajaran jarak jauh yaitu media pembelajaran yang diterapkan kurang kreatif dan inovatif sehingga rendahnya minat dan fokus siswa maka siswa kurangnya terlibat aktif dalam pembelajaran, hal tersebut dapat mempengaruhi nilai siswa. Penelitian ditujukan untuk menemukan jawaban dari efek perangkat pembelajaran Power Point interaktif pada nilai IPS siswa. Jenis penelitian "Kuantitatif Eksperimen" bermetode True Experiment Design, desain penelitian mempergunakan Posttest-Only Control Design, teknis sampel ialah Simple Random Sampling jumlahnya yaitu 56 dimana kelas eksperimen berjumlah 30 siswa serta kelas kontrol 26 siswa. Instrumen menggunakan soal multiple-choice, melalui uji valid menggunakan Poin Biserial dan reliabilitas menggunakan Kuder Richardson. Uji normalitas Liliefors, uji homogenitas Fisher. Lalu pengujian hipotesis pada uji- $t$ dan diperoleh thitung $=2,366$ untuk ttabel $=2,006$. Kesimpulannya t hitung $>\mathrm{t}$ tabel $(2,366>2,006)$ sehingga adanya pengaruh Powerpoint interaktif terhadap hasil belajar IPS siswa kelas V SD Islam Nurul Hidayah Depok.
\end{abstract}

Kata Kunci: Media Pembelajaran, Power Point Interaktif, Hasil Belajar.

\section{Abstract}

During the Covid-19 pandemic, distance learning was implemented, hence the need to pay attention to the learning process. Observations made by researchers found problems in the distance learning process, namely the learning media applied less creatively and innovatively so that the low interest and focus of students then students are less actively involved in learning, it can affect student grades. The research is intended to find answers to the effects of interactive PowerPoint learning tools on students' IPS scores. The type of research "Quantitative Experiment" with true experiment design method, research design using Posttest-Only Control Design, technical sample is Simple Random Sampling number is 56 where the experimental class numbered 30 students and control class 26 students. The instrument uses multiple-choice questions, through valid tests using Biserial Points and reliability using Richardson Kuder. Liliefors normality test, Fisher homogeneity test. Then the hypothesis test on the $t$-test and obtained thitung $=2.366$ for ttabel $=2.006$. In conclusion $t$ calculate $>t$ table (2,366 > 2,006) so that the influence of interactive Powerpoint on the results of ips learning students grade V SD Islam Nurul Hidayah Depok.

Keywords: Learning Media, Interaktif PowerPoint, Learning Outcomes.

Copyright (c) 2021 Hanny Pramitha Putri, Nurafni

$\triangle$ Corresponding author

Email : pramithahanny@gmail.com

DOI : https://doi.org/10.31004/edukatif.v3i6.986

ISSN 2656-8063 (Media Cetak)

ISSN 2656-8071 (Media Online) 
3539 Pengaruh Media Pembelajaran PowerPoint Interaktif terhadap Hasil Belajar IPS Siswa Sekolah DasarHanny Pramitha Putri, Nurafni

DOI: https://doi.org/10.31004/edukatif.v3i6.986

\section{PENDAHULUAN}

Sekolah ialah lembaga pendidikan berpusat untuk meningkatkan kecerdasan dan perilaku siswa (Suwartini, 2017) maka sekolah dijadikan tempat pelaksanaan pendidikan formal sejak dini yang memberikan kesempatan siswa untuk meningkatkan potensi, bakat serta minat melalui proses belajar (Arfani, 2016) menyatakan bahwa belajar dapat dikatakan suatu kegiatan untuk meningkatkan kecerdasan, ilmu, perubahan perilaku. Belajar dapat dikatakan suatu kegiatan yang dapat mengembangkan individu melalui pengalaman yang dimiliki sehingga berkaitan dengan keterampilan belajar yang dibimbing oleh guru.

Siswa mempunyai minat dan daya tarik berbeda-beda terhadap mata pelajaran yang diajarkan disekolah. prinsip belajar menunjukkan hal-hal utama yang harus dijalankan oleh guru sehingga pembelajaran berlangsung dengan memenuhi hasil optimal. Prinsip belajar memiliki pedoman dan wajib dilaksanakan guru guna siswa dapat memiliki peran aktif dalam proses belajar mengajar (Husamah et al., 2016). Faktor yang mempengaruhi nilai siswa ialah motivasi dan disiplin belajar (Lomu \& Widodo, 2018) maka belajar dapat dikatakan berhasil apabila memiliki keterampilan motivasi diri dan tidak mudah menyerah untuk memperoleh hasil optimal (Pratama et al., 2010). Tujuan belajar yaitu menciptakan pengalaman yang akan menjadi landasan kehidupan bagi siswa (Salam, 2017).

Mata pelajaran yang wajib diikuti siswa ialah Ilmu Pengetahuan Sosial yang biasa disingkat (IPS). Mata pelajaran tersebut wajib dipelajari siswa tetapi kenyataannya selama keadaan pandemi dan pembelajaran daring hasil belajar IPS siswa menurun salah satunya di sekolah yang saya lakukan penelitian yaitu SD Islam Nurul Hidayah Depok. Beberapa guru mendefinisikan IPS yang mempelajari tentang kelompok sosial berdasarkan pengalaman siswa sehingga dapat membantu siswa untuk dapat bersosialisasi dengan baik didalam masyarakat (Suwadi, 2019). Tujuan pembelajaran IPS agar siswa dapat dibimbing menjadi masyarakat Indonesia yang demokrat, tanggung jawab dan tentram (Fahreza \& Husna, 2017).

Semenjak meningkatnya wabah Covid-19 muncul kisaran pada awal bulan Maret 2020 Pemerintah Indonesia menyelenggarakan usaha cegah penularan virus covid-19, pemerintah memberlakukan segala kegiatan yang berpusat dirumah, serta dunia pendidikan terimbas merasakan dampaknya yaitu melakukan Pembelajaran Jarak Jauh (PJJ) yang berarti segala kegiatan-kegiatan serta pertemuan tatap muka langsung ditiadakan dan dilaksanakan secara daring atau online. Proses pembelajaran jarak jauh ini menyebabkan minat dan fokus siswa menjadi menurun maka siswa menjadi pasif dalam pembelajaran sehingga mempengaruhi nilai siswa (Cahyani et al., 2020).

Hasil belajar yaitu berupa penguasaan pemahaman siswa dalam semua aspek yang diperoleh melalui proses pembelajaran (Suminah et al., 2019). Observasi yang peneliti lakukan di SD Islam Nurul Hidayah Depok pada saat pembelajaran mata pelajaran IPS terdapat beberapa masalah karena kenyataannya mata pelajaran IPS penting dan wajib dipelajari siswa, tetapi rendahnya fokus dan minat siswa dikarenakan materi mata pelajaran IPS yang monoton dan terlalu banyak teks bacaan maka dianggap mudah atau sederhana sehingga siswa tidak berperan aktif dengan media pembelajaran yang diberikan oleh guru kurang kreatif dan inovatif karena minimnya pengetahuan yang lebih banyak mengenai media pembelajaran sehingga siswa mudah bosan dan tidak tertarik pada saat pembelajaran. Maka dengan kegiatan belajar yang memiliki masalah dapat mempengaruhi hasil akhir belajar contohnya seperti tugas atau ulangan harian terdapat beberapa siswa belum memenuhi KKM yang telah ditentukan nilai sebesar 75 .

Dengan berbagai pemasalahan proses belajar dan juga hambatan pembelajaran daring, saat kondisi pandemi seperti ini membuat peran teknologi semakin berkembang karena didalam pembelajaran daring ini diperlukannya fasilitas untuk melaksanakan pembelajaran yang maksimal dan efektif. Guru pun dituntut untuk lebih kreatif melaksanakan pembelajaran daring dengan menggunakan media yang membuat siswa tertarik dan semangat sehingga tidak mudah jenuh atau merasa bosan saat mengikuti pembelajaran daring, maka peneliti memberikan solusi yaitu memfasilitasi pembelajaran dengan media pembelajaran yang dapat 
meningkatkan ketertarikan siswa, karena adanya keunggulan dan manfaat dari media pembelajaran yaitu suatu alat untuk menyampaikan informasi untuk memancing pikiran, perhatian, dan minat siswa untuk mengikuti pembelajaran (Tafonao, 2018) sehingga dapat dibandingkan dengan media pembelajaran yang diterapkan oleh sekolah sebelumnya belum bersifat interaktif maka berpengaruh pada hasil belajar siswa. Oleh karena itu, perangkat pembelajaran dipergunakan sebagai daya tarik untuk siswa supaya mengikuti pembelajaran dengan baik salah satunya media pembelajaran interaktif yaitu pembelajaran berbasis teks interaktif berisikan materi. Melalui media pembelajaran interaktif ini siswa dapat berpartisipasi dalam kegiatan pembelajaran (Indriyanti, 2017). Media pembelajaran interaktif menggunakan Power Point. Program aplikasi Power Point digunakan untuk mengemas materi dengan ringkas, efektif dan mengaplikasikan animasi yang sangat lengkap (Srimaya, 2017).

Penelitian ini memiliki kelebihan karena menggunakan perangkat pembelajaran Power Point Interaktif yang dibuat sendiri oleh peneliti, dapat menyajikan teks materi pembelajaran, serta soal-soal dan gambar yang dapat bergerak atau bersifat interaktif yang sebelumnya belum pernah digunakan oleh guru dalam proses pembelajaran. Sehingga Power Point interaktif dapat meningkatkan minat, fokus dan aktifnya peran siswa saat belajar, harapannya dapat mempengaruhi hasil belajar. Penelitian serupa dilaksanakan (Sugama, 2018) bahwa dengan penerapan media pembelajaran Power Point Interaktif terdapat pengaruh pada nilai siswa. Sama halnya seperti penelitian yang dilakukan (Sumilat, 2018) tedapat peningkatan pada hasil belajar siswa dikarenakan memanfaatkan media pembelajaran interaktif.

Tujuan dilakukannya penelitian untuk membuktikan apakah adanya pengaruh Power Point interaktif terhadap hasil belajar IPS siswa kelas V di SD Islam Nurul Hidayah Depok. Hal tersebut merupakan suatu usaha agar tujuan pembelajaran dapat tercapai. Keberhasilan penelitian dapat dibuktikan dengan data kuantitatif yang diukur menggunakan statistik sederhana.

\section{METODE PENELITIAN}

Penelitian ini dilaksanakan di SD Islam Nurul Hidayah Depok pada semester genap tahun ajara 2021/2022 menggunakan jenis penelitian "Kuantitatif Eksperimen" dengan metode True Experiment Design, dengan melibatkan kelas V B yaitu kelompok eksperimen dan V C kelompok kontrol, desain penelitian menggunakan Posttest-Only Control Design. Populasi juga bukan hanya berupa jumlah yang tersedia tetapi secara keseluruhan karakteristik atau sifat pada obyek atau subyek tersebut. Populasi penelitian ini yaitu seluruh siswa kelas V sejumlah 85. Teknis pengambilan sampel menggunakan Simple Random Sampling (Sugiyono, 2018, p. 133). Sampel diperoleh sebanyak 56 siswa yaitu kelompok eksperimen 30 dan kelompok kontrol 26 siswa.

Tes adalah alat untuk mengukur dan menemukan adakah pengaruh atau tidak pada hasil akhir belajar IPS siswa dengan memanfaatkan media pembelajaran Power Point Interaktif. Jenis tes yang dipergunakan untuk mengambil data berupa tes pilihan ganda. Instrumen soal pilihan ganda sebanyak 40 soal sebelum digunakan perlu diuji apakah soal tersebut layak atau tidak untuk digunakan dalam penelitian melalui perhitungan uji validitas dengan rumus Poin Biserial jika perbutir soal tersebut $r_{\text {hitung }}>r_{\text {tabel }}$ maka dikatakan valid jika sebaliknya maka soal tersebut dikatakan drop atau tidak dapat digunakan. Lalu, soal yang dinyatakan valid perlu dilakukan pengujian reliabilitas menggunakan Kuder Richardson apabila $\mathrm{r}_{\text {hitung }}>\mathrm{r}_{\text {tabel }}$ maka instrumen data soal tersebut dinyatakan reliabel dan dapat digunakan untuk penelitian.

Langkah selanjutnya yaitu Uji normalitas dengan rumus Liliefors menggunakan data Post-test hasil belajar siswa untuk membuktikan apakah data tersebut normal atau tidak jika Lo $<$ Ltabel maka data tersebut berdistribusi normal. Langkah selanjutnya yaitu uji homogen menggunakan rumus Fisher apabila Fo < Ftabel maka data dapat dinyatakan homogen, langkah terakhir yaitu uji hipotesis dengan rumus uji- $t$ jika thitung > ttabel maka dapat disimpulkan bahwa $\mathrm{H}_{0}$ ditolak dan $\mathrm{H}_{1}$ diterima artinya terdapat pengaruh media 
3541 Pengaruh Media Pembelajaran PowerPoint Interaktif terhadap Hasil Belajar IPS Siswa Sekolah Dasar Hanny Pramitha Putri, Nurafni

DOI: https://doi.org/10.31004/edukatif.v3i6.986

pembelajaran terhadap hasil belajar IPS siswa. Penelitian ini menggunakan teknik statistik yang dipergunakan ialah teknik statistik deskriptif.

\section{HASIL DAN PEMBAHASAN PENELITIAN}

Tabel 1. Hasil Perhitungan Uji Normalitas Hasil Belajar

\begin{tabular}{|c|c|c|c|c|}
\hline Kelompok & Lhitung & Ltabel & Kriteria & Keterangan \\
\hline Eksperimen & 0,135 & 0,161 & \multirow{2}{*}{ Lo $<$ Ltabel } & \multirow{2}{*}{ Normal } \\
\hline Kontrol & 0,157 & 0,174 & & \\
\hline
\end{tabular}

Pada tabel 1 diatas, uji normalitas dilakukan mempergunakan uji liliefors. Hasil perhitungan kelompok eksperimen dan kelompok kontrol menunjukkan (Lo $<$ Ltabel) pada taraf signifikansi $\alpha=0,05 \mathrm{n}=30$ kelompok eksperimen dan 26 kelompok kontrol sehingga disimpulkan bahwa data hasil belajar pada penelitian ini berdistribusi normal.

Tabel 2. Hasil Uji Homogenitas Data Hasil Belajar

\begin{tabular}{|c|c|c|c|c|c|}
\hline Kelompok & Varians & Fhitung & Ftabel & Kriteria & Keterangan \\
\hline Eksperimen & 127,059 & \multirow{2}{*}{1,192} & \multirow{2}{*}{1,926} & \multirow{2}{*}{ Fo $<$ Ftabel } & \multirow{2}{*}{ Homogen } \\
\hline Kontrol & 106,634 & & & & \\
\hline
\end{tabular}

Pada tabel 2 diatas dilakukan uji homogen menggunakan rumus uji Fisher. Diperoleh nilai Ftabel sebesar 1,926 dan $F o$ sebesar 1,192. Dengan dk pembilang $=29$ dan dk penyebut $=25$ serta taraf signifikansi $\alpha=0,05$. Maka dikarenakan $F o<$ Ftabel yaitu sebesar $(1,192<1,926)$ kesimpulan data tersebut bersifat homogen.

Setelah dilakukan penghitungan uji normalitas dan uji homogen sehingga data tersebut dikatakan normal dan homogen maka data dapat diuji hipotesis menggunakan rumus uji-t thitung $=2,366$ taraf signifikansi $\alpha=0,05$ derajat kebebasan $(\mathrm{dk})=54$ senilai 2,006. Maka diperoleh hasil thitung lebih besar dari ttabel sebesar ( 2,366 > 2,006 ) sehingga dapat disimpulkan bahwa adanya pengaruh media pembelajaran PowerPoint interaktif terhadap hasil belajar IPS.

Berdasarkan penelitian diatas, diketahui bahwa media pembelajaran Power Point interaktif ini tepat digunakan dan dapat dijadikan solusi permasalahan penelitian ini pada siswa karena menurunnya hasil belajar IPS siswa saat pandemi dikarenakan rendahnya minat, fokus dan siswa kurang terliba aktifdalam pembelajaran berlangsung. Adanya perbedaan pada kedua kelompok yang akan diteliti, untuk kelompok eksperimen akan mendapatkan perlakuan dengan diterapkannya media pembelajaran Power Point Interaktif dimana pada saat pembelajaran sebelumnya belum pernah diterapkan oleh guru sehingga dapat meningkatkan ketertarikan siswa terhadap pembelajaran dan memiliki minat, fokus serta terlibat aktif yang tinggi dalam pembelajaran sesuai dengan harapan yang peneliti inginkan yaitu adanya pengaruh terhadap hasil belajar IPS dengan penerapan media pembelajaran Power Point interaktif ini, tetapi adanya perbedaan proses pembelajaran pada kelompok kontrol tidak mendapatkan perlakuan yang sama dengan kelompok eksperimen. Lalu diakhir pembelajaran, guru memberikan soal Post-test melalui Google-Form.

Penelitian ini serupa dengan penelitian yang dilakukan oleh (Nurwidayanti \& Mukminan, 2018) bahwa nyatanya hubungan perangkat pembelajaran dapat memengaruhi perolehan nilai siswa dan relevan dengan penelitian yang dilakukan oleh (Zulhelmi et al., 2017) bahwa terbukti adanya perbedaan peningkatan keterampilan berpikir kritis siswa yang dipengaruhi oleh media pembelajaran interaktif. Sehingga penyataan penelitian yang dilakukan (Novita et al., 2019) membuktikan bahwa penggunaan media pembelajaran yang inovatif dapat memberikan pengaruh yang signifikan untuk meningkatkan hasil belajar. Serupa dengan penelitian (Wahyuningtyas \& Sulasmono, 2020) dalam penggunaan media dalam kegiatan belajar tentunya 
terbukti dapat meningkatkan pemahaman dan hasil akhir siswa. Maka berdasarkan pemaparan diatas, sebaiknya guru meningkatkan penguasaan teknologi yang terus berkembang agar proses pembelajaran dapat berjalan secara optimal dan perlunya memperhatikan perangkat pembelajaran dengan menggunakan media pembelajaran kreatif dan inovatif sehingga menjadi daya tarik siswa selama kegiatan belajar dalam pemanfaatan perangkat pembelajaran.

Keterbatasan yang dihadapi pada saat melaksanakan penelitian ini dikarenakan masih dalam keadaan pandemi Covid-19 dan pembelajaran virtual atau online yang lebih dikenal pembelajaran jarak jauh pastinya adanya kendala yang dialami saat proses pembelajaran berlangsung, keterbatasan perangkat atau gadget yang dimiliki siswa, terlambat memasuki ruang Zoom-Meeting, dan kuota internet yang tidak cukup bahkan terkadang jaringan internet yang tidak mendukung sehingga dapat mengganggu proses pembelajaran dengan menampilkan Power Point interaktif melalui aplikasi Zoom Meeting contoh kendala yaitu tampilan Power Point interaktif yang tidak terlihat dilayar siswa atau suara terputus-putus sehingga sebagai guru harus memperhatikan jaringan dan kondisi siswa saat pembelajaran dan selalu memberikan penguatan setiap pembelajaran maka dengan keterbatasan penelitian ini memiliki dampak yaitu kurang maksimal dalam pelaksanaannya. Solusi yang harus diterapkan yaitu guru harus mempersiapkan secara optimal untuk melaksanakan pembelajaran dan memperhatikan kendala yang telah dialami sebelumnya sehingga dapat teratasi, lalu dapat mengkomunikasikan kepada orang tua murid agar mempersiapkan segala kebutuhan pembelajaran daring dirumah supaya pembelajaran dapat berjalan sesuai harapan, dan mencapai tujuan pembelajaran hingga mencapai hasil yang diharapkan, dalam penelitian ini tentunya memiliki makna terhadap perkembangan keilmuan yaitu bertujuan untuk membuktikan kebenaran.

\section{KESIMPULAN}

Penelitian ini terbukti berpengaruh pada hasil belajar IPS siswa dengan digunakannya media pembelajaran Power Point interaktif. Tentunya memberikan poin positif sehingga dapat dijadikan solusi untuk guru agar menciptakan pembelajaran yang lebih baik sehingga siswa antusias terhadap kegiatan pembelajaran. Pembelajaran yang berlangsung menggunakan media pembelajaran Power Point interaktif memperoleh beberapa faktor yaitu meningkatkan minat, fokus dan keaktifan siswa saat pembelajaran berlangsung sehingga tidak mudah bosan atau jenuh.

\section{DAFTAR PUSTAKA}

Arfani, L. (2016). Mengurai Hakikat Pendidikan, Belajar Dan Pembelajaran. 11(2), 81-97.

Cahyani, A., Listiana, I. D., \& Larasati, S. P. D. (2020). Motivasi Belajar Siswa SMA Pada Pembelajaran Daring Di Masa Pandemi Covid-19. IQ (Ilmu Al-Qur'an): Jurnal Pendidikan Islam, 3(01), 123-140. Https://Doi.Org/10.37542/Iq.V3i01.57

Fahreza, F., \& Husna, N. (2017). Pengaruh Strategi Pembelajaran Terhadap Hasil Belajar IPS Siswa Kelas V SD Negeri Paya Peunaga Kabupaten Aceh Barat. Jurnal Bina Gogik, 4(2), 37-48. Http://Www.Ejournal.Stkipbbm.Ac.Id/Index.Php/Pgsd/Article/View/11/10

Husamah, Pantiwati, Y., Restian, A., \& Puji, S. (2016). Belajar Dan Pembelajaran. Univesitas Muhammadiyah Malang.

Indriyanti, N. Y. (2017). Pengembangan Media Pembelajaran Interaktif Berbasis Ppt Untuk Meningkatkan Hasil Belajar Ips Materi Keragaman Suku Bangsa Dan Budaya Studi Kasus : Siswa Kelas Vb Sdn Karangayu 02 Kota Semarang. 1-146.

Lomu, L., \& Widodo, S. A. (2018). Pengaruh Motivasi Belajar Dan Disiplin Belajar Terhadap Prestasi Belajar Matematika Siswa. Prosiding Seminar Nasional Pendidikan Matematika Etnomatnesia, 0(0), 745-751. 
3543 Pengaruh Media Pembelajaran PowerPoint Interaktif terhadap Hasil Belajar IPS Siswa Sekolah Dasar Hanny Pramitha Putri, Nurafni

DOI: https://doi.org/10.31004/edukatif.v3i6.986

Novita, L., Sukmanasa, E., \& Pratama, M. Y. (2019). Penggunaan Media Pembelajaran Video Terhadap Hasil Belajar Siswa SD. Indonesian Journal Of Primary Education Penggunaan, 3(2), 64-72. Http://Ejournal.Upi.Edu/Index.Php/IJPE/Index

Nurwidayanti, D., \& Mukminan, M. (2018). Pengaruh Media Pembelajaran Terhadap Hasil Belajar Ekonomi Ditinjau Dari Gaya Belajar Siswa SMA Negeri. Harmoni Sosial: Jurnal Pendidikan IPS, 5(2), 105-114. Https://Doi.Org/10.21831/Hsjpi.V5i2.17743

Pratama, F., Firman, \& Neviyarni. (2010). Pengaruh Motivasi Belajar IPA Siswa Terhadap Hasil Belajar. EDUKATIF: Jurnal Ilmu Pendidikan, 280-286. Https://Edukatif.Org/Index.Php/Edukatif/Index\%0apengaruh

Salam, R. (2017). Model Pembelajaran Inkuiri Sosial Dalam Pembelajaran Ips. Harmony: Jurnal Pembelajaran IPS Dan Pkn, 2(1), 7-12.

Srimaya. (2017). Efektivitas Media Pembelajaran Power Point Untuk Meningkatkan Motivasi Dan Hasil Belajar Biologi Siswa. Jurnal Biotek, 5(1), 53-68. Http://Journal.UinAlauddin.Ac.Id/Index.Php/Biotek/Article/View/3446

Sugama, R. D. (2018). Pengaruh Media Pembelajaran Powerpoint Interaktif Terhadap Hasil Belajar Peserta Didik Pada Mata Pelajaran Ekonomi Kelas X IPS 3 SMA Negeri 9 Bandung. Http://Repository.Unpas.Ac.Id/Id/Eprint/39926

Sugiyono. (2018). Metode Penelitian Kuantitatif (Setiyawami (Ed.); 1st Ed.). Alfabeta.

Sumilat, J. M. (2018). Pemanfaatan Media Pembelajaran Matematika Interaktif Untuk Meningkatkan Hasil $\begin{array}{lllllll}\text { Belajar } & \text { Siswa } & \text { Di } & \text { SD } & \text { Negeri } & 2 & \text { Tataaran. }\end{array}$ Https://Doi.Org/Https://Doi.Org/10.36456/Inventa.2.1.A1624

Suminah, S., Gunawan, I., \& Murdiyah, S. (2019). Peningkatan Hasil Belajar Dan Motivasi Belajar Siswa Melalui Pendekatan Behavior Modification. Ilmu Pendidikan: Jurnal Kajian Teori Dan Praktik Kependidikan, 3(2), 221-230. Https://Doi.Org/10.17977/Um027v3i22018p221

Suwadi, S. (2019). Pengembangan Media Grafis Dalam Pembelajaran IPS Untuk Inpres Unggulan BTN Pemda Kota Makassar Development Of Graphic Media In IPS Learning To Grow The Interest Of Learning Students In The Private Vocational Program Pascasarjana.

Suwartini, E. A. (2017). Supervisi Akademik Kepala Sekolah, Profesionalisme Guru Dan Mutu Pendidikan. Jurnal Administrasi Pendidikan, 24(2), 62-70. Https://Doi.Org/10.17509/Jap.V24i2.8294

Tafonao, T. (2018). Peranan Media Pembelajaran Dalam Meningkatkan Minat Belajar Mahasiswa. Jurnal Komunikasi Pendidikan, 2(2), 103. Https://Doi.Org/10.32585/Jkp.V2i2.113

Wahyuningtyas, R., \& Sulasmono, B. S. (2020). Pentingnya Media Dalam Pembelajaran Guna Meningkatkan Hasil Belajar Di Sekolah Dasar. Edukatif: Jurnal Ilmu Pendidikan, 2(1), 23-27. Https://Doi.Org/10.31004/Edukatif.V2i1.77

Zulhelmi, Adlim, \& Mahidin. (2017). Pengaruh Media Pembelajaran Interaktif Terhadap Peningkatkan Keterampilan Berpikir Kritis Siswa. Jurnal Pendidikan Sains Indonesia (Indonesian Journal Of Science Education), 5(1), 72-80. 